\title{
KSZTALCENIE KOMPETENCJI TRANSLATORYCZNEJ ROZWAŻANIA TEORETYCZNE I METODOLOGICZNE
}

\begin{abstract}
Słowa kluczowe: kompetencja translatoryczna, metodyka nauczania języków obcych, przekładoznawstwo, dydaktyka przekładu, nauczanie języka polskiego jako obcego, programy kształcenia thumaczy.

Streszczenie. Celem niniejszego artykułu jest przedstawienie wybranych definicji i koncepcji kompetencji translatorycznej, głównie w oparciu o prace anglojęzyczne. Autor wychodzi od najwcześniejszych prac generatywistów i pokrótce charakteryzuje początki prac nad teoretycznymi podwalinami kompetencji translatorycznej. W dalszej części artykułu zostaną przedstawione najważniejsze zmiany i nurty w badaniach nad kompetencją - przede wszystkim osiągnięcia hiszpańskiej grupy badawczej PACTE oraz tzw. definicja minimalistyczna Pyma. W końcowej części artykułu autor postara się udzielić odpowiedzi na pytanie, jakie są glottodydaktyczne implikacje wyłaniające się z różnych definicji kompetencji translatorycznej. W oparciu o teorię „kompetencji przedtłumaczeniowej" (ang. pretranslation competence) w ujęciu Presas (2000), spróbuje wskazać różnice pomiędzy procesem kształcenia językowego na filologiach a na studiach thumaczeniowych.
\end{abstract}

\section{POTRZEBA NOWEJ DEFINICJI KOMPETENCJI TEUMACZENIOWEJ}

Na przestrzeni ostatnich lat zauważalne są wyraźne zmiany na polu nauk przekładoznawczych. Translatologia nie tylko prężnie się rozwija, usamodzielnia, wyraźnie odcinając się od innych dyscyplin, w których była dotychczas osadzona, ale przede wszystkim zaczęła z nich czerpać, dzięki czemu uzyskała status dziedziny interdyscyplinarnej. Celem niniejszego artykułu jest nie tyle przyjrzenie się ewolucji badań nad przekładem, ile postawienie pytania o potrzebę rewizji teo-

*kszafran@uni-mainz.de, Uniwersytet im. Jana Gutenberga w Moguncji, Wydział Translatoryki, Lingwistyki i Kulturoznawstwa (FTSK), Zakład Polonistyki, An der Hochschule 2, 76726 Germersheim, Niemcy. 
rii dotyczących tzw. kompetencji translatorycznej ${ }^{1}$. Kolejnym istotnym aspektem będzie zrewidowanie tego, czy zmiana spojrzenia na kompetencję thumaczeniową wywrze wpływ na sposób kształcenia językowego tłumaczy.

Głównym argumentem przemawiającym za potrzebą przedefiniowania bądź zmodernizowania wyobrażenia o kompetencji tłumaczeniowej jest fakt, że oprócz wspomnianego już rozwoju teoretycznego przekładoznawstwa, wiodącym motorem zmian jest rewolucja technologiczna, a konkretnie ekspansja narzędzi CAT (computer assisted translation), które w znaczącym stopniu zmieniły warsztat pracy tłumacza. Można przypuszczać, że na przestrzeni kilku lub kilkunastu lat jego głównym zadaniem będzie przede wszystkim korygowanie i kontrolowanie maszynowo przełożonych tekstów. Narzędzia CAT mają obecnie największy wpływ na przekład pisemny, jednak należy się spodziewać, że wraz z zaawansowaniem prac nad sztuczną inteligencją również tłumaczenie ustne będzie czerpało korzyści z nowej technologii.

Do kolejnych przemian na rynku translatorskim należy zaliczyć 3 inne istotne czynniki. Są to: profesjonalizacja, globalizacja i specjalizacja (Biel 2011, s. 163). Najistotniejszą rolę, z punktu widzenia problematyki nauczania języka, odgrywa w tym przypadku specjalizacja, która w znacznym stopniu wpływa na proces kształcenia. Od adeptów sztuki tłumaczenia oczekuje się o wiele bardziej wyspecjalizowanej, skonkretyzowanej wiedzy, np. w dziedzinie prawa, ekonomii czy medycyny niż od studentów filologii. Istotne jest przy tym jednak, aby tłumacze nie mieli zbyt wielu specjalizacji, ale raczej wybrali jedną czy dwie dziedziny, w których będą dążyć do perfekcji.

W obliczu tych zmian wydaje się, że konieczność zweryfikowania dotychczasowych opracowań dotyczących definicji kompetencji thumacza, a także związanych z nią implikacji glottodydaktycznych jest w pełni uzasadnione.

\section{POCZĄTKI I ROZWÓJ BADAŃ NAD KOMPETENCJĄ TRANSLATORYCZNĄ}

\subsection{PRACE GENERATYWISTÓW}

Jedną z pierwszych prób opisania kompetencji translatorycznej można znaleźć $\mathrm{u}$ niemieckiego językoznawcy W. Willsa w pracy Perspectives and limitations of a didactic framework for the teaching of translation z 1976 roku. Wills początkowo

${ }^{1} \mathrm{~W}$ literaturze anglojęzycznej spotykamy się najczęściej z pojęciem „translation competence“, w pracach polskojęzycznych funkcjonuje kilka przekładów tego terminu, najczęstsze to „,kompetencja translatoryczna” lub „kompetencja przekładowa”. Tych dwóch nazw będę używał w charakterze synonimicznym. 
twierdził, że właściwie nie ma konkretnej definicji ani dającego się wyodrębnić zasobu wiedzy, który tłumacz powinien posiadać (Wills 1976, s. 119), i jak zauważa Pym, jest to uwaga poniekąd słuszna, gdyż zwłaszcza teraz, w dobie gwałtownych przemian technologicznych i społecznych należy się spodziewać, że kompendium wiedzy niezbędnej do thumaczenia również ulega ciągłej rewolucji i zmianie (Pym 2013, s. 482). Mimo to Wills zamieszcza kilka wskazówek i przemyśleń, które mogą służyć za podstawę definicyjną. Niezgodnie z tym, co badacz deklarował na początku swojego artykułu, w dalszej jego części postuluje, że każdy tłumacz powinien posiąść 4 zakresy kompetencji w każdym języku (w sumie osiem kompetencji), których połączenie na tym samym poziomie stanowi kompetencję thumaczeniową (Wills 1976, s. 20). Takie rozumienie kompetencji opiera się zatem na założeniu, że suma różnych kompetencji lingwistycznych jest równoważna z posiadaniem warsztatu tłumacza. W podobnym duchu wypowiadał się również inny badacz wywodzący się ze szkoły generatywnej - Harris (1977), który uważał, że każda osoba bilingwalna jest ,naturalnym thumaczem”, ponieważ perfekcyjna znajomość dwóch języków jest równoznaczna $\mathrm{z}$ umiejętnością tłumaczenia. Założenia tego typu nie są jednak słuszne, gdyż znajomość języka, choć kluczowa i niezbędna, i będąca bez wątpienia warunkiem koniecznym, jest niewystarczająca do wykonywania zawodu thumacza. Mimo to w latach 70. i 80. XX wieku tego typu przekonanie dominowało w wielu pracach (por. Koller 1979; Harris, Sherwood 1978; Wilss 1982; Ballard 1984). Dopiero w późniejszych badaniach (por. Krings 1986; Lörscher 1991; Kussmaul 1995; Presas 2000) stwierdzono, że choć można mówić o tzw. kompetencji bilingwalnej, to nie jest ona równoznaczna z kompetencją translatoryczną. Rozgraniczenie tych dwu pojęć dało przede wszystkim impuls do dalszych badań w tej dziedzinie i zasadniczej zmiany perspektywy - choć kompetencje w obu językach są absolutnie konieczne do tego, aby móc sprawnie thumaczyć, to nie są one z pewnością jedynymi składowymi kompetencji tłumaczeniowej².

\subsection{GRUPA BADAWCZA PACTE}

Najbardziej interesujące i przełomowe badania zaczęły się tak naprawdę rozwijać z końcem lat 90. XX wieku, kiedy w 1997 roku została zawiązana grupa badawcza PACTE³, skupiająca początkowo naukowców z Hiszpanii, jednak z czasem również z innych krajów, m.in. z Polski. Naukowcy z tej grupy traktują kompetencję translatoryczną w sposób holistyczny i definiują ją jako „zasadniczy

${ }^{2}$ Obszerny opis i przegląd różnych starszych definicji kompetencji tłumaczeniowej oraz pojęć jej towarzyszących zamieścili Orozco, Hurtado Albir (2002) oraz Pym (2003).

${ }^{3}$ Nazwa grupy PACTE wywodzi się z hiszpańskiego Procés d'Adquisició de la Competència Traductora i Avaluació. 
system wiedzy i umiejętności, potrzebny do tłumaczenia" (PACTE 2000, s. 100). Autorzy definicji podkreślają, że choć bazuje ona na wcześniejszych podejściach lingwistycznych, to rozszerzono ją przede wszystkim o elementy związane ze strategią thumaczenia oraz czynniki psychologiczno-fizjologiczne. W kolejnych latach dołączono również pięć twierdzeń towarzyszących:

1. „kompetencja translatoryczna jest jakościowo różna od kompetencji bilingwalnej;

2. kompetencja translatoryczna jest zasadniczym systemem wiedzy, potrzebnym do thumaczenia;

3. kompetencja translatoryczna jest wiedzą ekspercką i jak każda wiedza ekspercka składa się z wiedzy deklaratywnej i proceduralnej, przy czym wiedza proceduralna jest dominująca;

4. na kompetencję translatoryczną składa się system subkompetencji, które są ze sobą wzajemnie powiązane, hierarchiczne, jednak system tych powiązań może ulegać zmianom;

5. za subkompetencje thumaczeniowe uważa się:

a) kompetencję językową w dwu językach;

b) subkompetencję pozajęzykową,

c) subkompetencję instrumentalną/zawodową,

d) subkompetencję psychofizjologiczną,

e) subkompetencję transferową,

f) subkompetencję strategiczną"4 (PACTE 2003, s. 6).

Poniższy schemat przedstawia system relacji pomiędzy poszczególnymi kompetencjami:

Schemat 1. System relacji między kompetencjami translatorycznymi

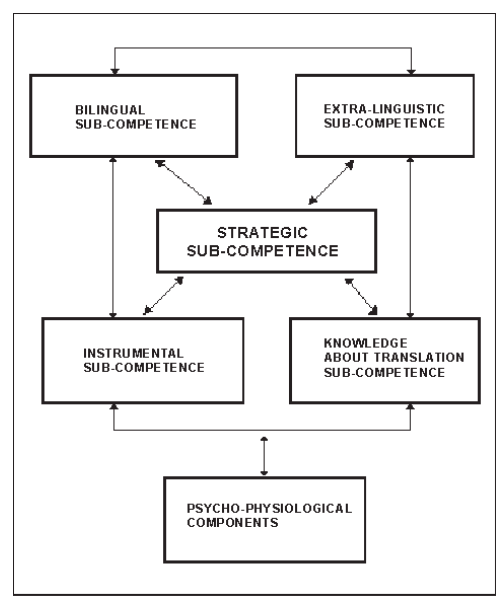

Źródło: PACTE 2003, s. 18

${ }^{4}$ Tłumaczenie własne. 
Początkowe podejście lingwistyczne zastąpiono komunikacyjnym, które kładzie zdecydowanie większy nacisk na rozróżnienie pomiędzy wiedzą (kompetencją) a realizacją bądź aktywizacją tej wiedzy w poszczególnych warunkach psychologicznych lub kontekstualnych (tłumaczeniem), zaznaczając przy tym, że kompetencja tłumaczeniowa różni się od komunikacyjnej w głównej mierze tym, że jest ona rodzajem wiedzy eksperckiej (PACTE 2003, s. 3-4). Poszczególne subkompetencje zostały zdefiniowane w następujący sposób:

1. subkompetencja dwujęzyczna (bilingual sub-competence): składa się na nią w głównej mierze wiedza proceduralna, z uwzględnieniem kontroli interferencji w procesie zmiany języka. Ponadto należy do niej znajomość konwencji: pragmatycznych, socjolingwistycznych (wraz z umiejętnością różnicowania rejestru językowego oraz znajomością dialektów, do których włączone są również socjolekty i slang), tekstowych (mechanizmy koherencji i kohezji, zróżnicowanie gatunkowe), gramatyczno-leksykalnych (słownictwo, morfologia, składnia, fonologia i grafologia) w obu językach;

2. subkompetencja pozajęzykowa (extra-linguistic sub-competence): wiedza w głównej mierze o charakterze deklaratywnym, zarówno implicytna, jak i eksplicytna, obejmująca wiedzę dwukulturową, encyklopedyczną oraz wyspecjalizowaną;

3. subkompetencja wiedzy o thumaczeniu (knowledge of translation sub-competence): deklaratywna wiedza (implicytna i eksplicytna) dotycząca zarówno samego procesu funkcjonowania thumaczenia (metod, strategii, technik), jak i przebiegu pracy thumacza (różne typy zleceń, oczekiwań i wymagań klientów itp.);

4. subkompetencja instrumentalna (instrumental sub-competence): wiedza proceduralna, na którą składa się znajomość dostępnych narzędzi translacyjnych;

5. subkompetencja strategiczna (strategic sub-competence): wiedza proceduralna, mająca umożliwić proces translacji, mierzenie się z potencjalnymi trudnościami podczas tłumaczenia i wyeliminowanie błędów. Badacze uznali tę kompetencję za najważniejszą - stąd jej umiejscowienie w środku schematu - ponieważ kontroluje proces thumaczenia. Kompetencja strategiczna umożliwia:
a) zaplanowanie procesu thumaczenia (wybór odpowiedniej metody),
b) ewaluację procesu (również na poszczególnych etapach pracy),
c) aktywację innych subkompetencji,
d) identyfikację problemów tłumaczeniowych oraz zastosowanie technik, które je niwelują;

6. komponenty psychofizjologiczne (psycho-physiological components): zarówno kognitywne, jak i behawioralne, związane z zachowaniami psychomotorycznymi. Wyszczególniono trzy typy komponentów:
a) kognitywne (pamięć, percepcja, uwaga, emocje),
b) behawioralne (m.in. intelektualna ciekawość, motywacja),
c) zdolności, takie jak kreatywność, umiejętność logicznego myślenia,
d) zdolności analityczne i syntetyczne (PACTE 2003, s. 16-17). 
Wydaje się, że rozumienie kompetencji w ujęciu grupy PACTE jest najobszerniejsze i najpełniejsze. Największą wartość ma przede wszystkim wydzielenie różnego typu subkompetencji oraz ich szczegółowy opis.

\subsection{KOMPETENCJA PRZEDTŁUMACZENIOWA}

PACTE zajęła się nie tylko modelowaniem definicji kompetencji tłumaczenia, ale skupiła również uwagę na mechanizmach i procesie nauczania thumaczenia, co w badaniach nad kompetencją translatoryczną jest stosunkowo rzadkie. W 2000 roku grupa opublikowała następujący schemat nauczania kompetencji thumaczeniowej:

Schemat 2. Nauczanie kompetencji thumaczeniowej

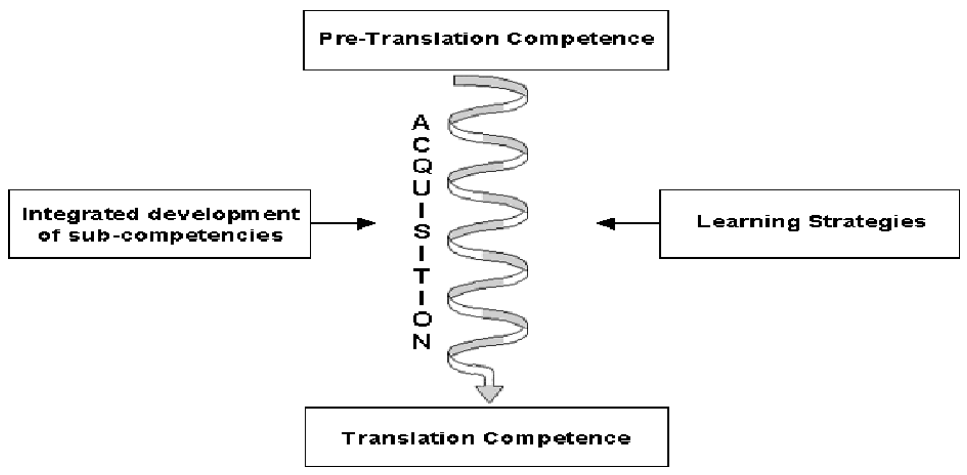

Źródło: PACTE 2000, s. 104

Autorzy modelu uważają, że kształcenie kompetencji tłumaczeniowej jest procesem:

1. dynamicznym i spiralnym - rozróżnia się w nim wiedzę początkową (kompetencję przedttumaczeniową) oraz wiedzę ekspercką (kompetencję thumaczeniową). Do rozwijania kompetencji translatorycznej potrzebne są strategie uczenia się oraz wiedza deklaratywna i proceduralna, która musi być w odpowiedni sposób włączana do programu nauczania, rozwijana i strukturyzowana;

2. w którym rozwój wiedzy proceduralnej, a także w efekcie subkompetencji strategicznej jest kluczowy;

3. podczas którego subkompetencje wchodzące w skład kompetencji tłumaczeniowej rozwijają się i ulegają restrukturyzacji (PACTE 2003, s. 8).

Za najważniejsze, biorąc zwłaszcza pod uwagę wpływ na proces kształcenia językowego przyszłych tłumaczy, uważam przede wszystkim wyraźnie wskazanie na zasadnicze różnice metodyczne w zależności od kierunku thumaczenia - na język 
pierwszy bądź na język obcy. Zarówno relacje pomiędzy poszczególnymi subkompetencjami, jak i tempo ich rozwoju mogą być znacząco odmienne. Problemem tym zajmuje się, choć niestety w niewielkim stopniu, należąca do grupy PACTE Marisa Presas, która w krótkim artykule (1998) jedynie zasygnalizowała cztery istotne czynniki, wpływające na rozwijanie kompetencji przedtłumaczeniowej.

1. Pierwszy czynnik związany jest z typem dwujęzyczności. Badaczka opiera się na lingwistycznych teoriach tego zjawiska w ujęciu Bloomfielda (1933) i Weinreicha (1968), wychodząc z założenia, że bilingwizm przyszłych tłumaczy różni się od tego we wspomnianych pracach. Kompetencje lingwistyczne tłumacza są bowiem bardziej wyspecjalizowane niż u innych użytkowników języka i ma to związek przede wszystkim z rodzajem thumaczenia (ustnym bądź pisemnym) oraz z jego kierunkiem (z J1 na J2 bądź odwrotnie).

2. Kolejnym istotnym czynnikiem jest struktura pamięci thumaczy, a mianowicie relacje pomiędzy elementami lingwistycznymi i reprezentacjami mentalnymi. W swoich badaniach Presas odwołuje się do podziału S. Ervin i C.E. Osgooda (1954), sprowadzając trzy rodzaje dwujęzyczności do dwóch: złożonego (compound) i współrzędnego (coordinate). Pierwszy łączy dwa systemy lingwistyczne z jednym konceptualnym, drugi z kolei posiada jeden system reprezentacji mentalnych połączony z jednym językiem. Zdaniem badaczki punktem wyjścia do rozważań nad kształceniem tłumaczy jest konfiguracja typu pamięci - złożona lub skoordynowana. Jest to ściśle powiązane z rozdzieleniem nie tylko dwóch systemów językowych, ale też dwóch systemów koncepcji mentalnych (Presas 1998, s. 131-132). Według autorki te dwa czynniki - wiedza lingwistyczna i pamięć bilingwalna - są bazą (kompetencją przedtłumaczeniową), na której rozbudowuje się warsztat thumacza.

3. Kolejną ważną rzeczą, która wpływa na doskonalenie umiejętności tłumaczenia jest kontrola nad dwoma procesami:

a) mieszaniem kodów, który jest zasadniczo, np. w socjolingwistyce, oceniany jako zjawisko negatywne, jednak w rozważaniach nad kompetencją tłumaczeniową może mieć charakter pozytywny, gdyż jest rozumiany jako ,automatyczny mechanizm asocjacyjny”;

b) interferencją językową, która, podobnie jak mieszanie kodów, nie jest rozumiana wyłącznie negatywnie.

4. Ostatnim z czynników jest kompetencja kulturowa, na którą składa się m.in. wiedza o świecie oraz znajomość poziomu nieformalnego języka (Presas 1998, s. 132-133).

Niestety poza tymi wstępnymi uwagami badaczka nie zamieściła żadnych praktycznych wskazówek, w jaki sposób wspomniane przez nią elementy powinny być uwzględnione w programach nauczania. 


\subsection{KOMPETENCJA MINIMALISTYCZNA}

W opozycji do obszernej definicji kompetencji translatorycznej w opracowaniu grupy PACTE w 2003 roku australijski naukowiec A. Pym zaproponowal koncepcję „minimalistyczną”. Jego zdaniem kompetencja thumaczeniowa składa się jedynie z dwu elementów, którymi są:

1. „umiejętność wygenerowania serii więcej niż jednej realizacji tekstu docelowego $\left(\mathrm{TT}_{1}, \mathrm{TT}_{2} \ldots \mathrm{TT}_{\mathrm{n}}\right)$ dla odpowiedniego tekstu wyjściowego $\left(\mathrm{ST}^{5}\right)$;

2. umiejętność wybrania $\mathrm{z}$ tej serii jednej realizacji w sposób szybki oraz zasadny" (Pym 2003, s. 489).

Badacz dowodzi, że thumacz potrzebuje do tego celu niezwykle obszernego zasobu różnych umiejętności, na które składają się m.in. znajomość gramatyki, leksyki, stylistyki, a także szereg umiejętności pozajęzykowych. Decydującą rolę w procesie tłumaczenia odgrywają jednak dwie rzeczy - generowanie tekstów o charakterze synonimicznym i wybieranie najlepszej wersji spośród nich. Choć nie sposób się z Pymem nie zgodzić, to wydaje się jednak, że takie spłaszczenie rozumienia kompetencji thumaczeniowej nie jest, zwłaszcza z dydaktycznego punktu widzenia, pomocne w kształceniu tłumaczy. Badacz jest jednak odmiennego zdania - uważa, że dzięki jego teorii można w sposób jasny rozgraniczyć naukę języka ogólnego od kształcenia tłumaczy. W jego ujęciu naukę języka ogólnego powinna cechować: analityczność, uniwersalne reguły i zorientowanie na gramatykę, a kształcenie tłumaczy powinno wyróżniać się nieanalitycznością, umiejscowieniem w konkretnym kontekście oraz zorientowaniem na przykłady (Pym 2013, s. 492). Niestety, badacz nie rozwija tego tematu i nie podaje konkretnych wytycznych, jak taki program miałby wyglądać. Zaskakujące jest również niezwykle lakoniczne i uproszczone podejście do nauczania języka obcego, które zostało zredukowane do zaledwie dwóch zasad, co znacząco odbiega od ogólnie przyjętych teorii glottodydaktycznych.

\section{IMPLIKACJE GLOTTODYDAKTYCZNE}

Metodyka nauczania kompetencji translatorycznej jest stosunkowo nową dziedziną, która nie doczekała się jeszcze wielu opracowań badawczych w języku polskim, zwłaszcza zajmujących się problematyką nauczania polskiego. Z zaprezentowanych wybranych aspektów dotyczących teorii kompetencji thumacze-

\footnotetext{
${ }^{5}$ Stosuję skróty z języka angielskiego TT - target text 'tekst docelowy' oraz ST - source text 'tekst wyjściowy'.

${ }^{6}$ Tłumaczenie własne.
} 
niowej wynikają dwa ważne przesłania. Pierwsze wydaje się mieć znaczenie fundamentalne - kształcenie tłumacza nie jest częścią studiów filologicznych (Snell-Hornby 1994) i powinno cechować się innymi celami oraz metodami dydaktycznymi. Tezę tę wysunęła M. Snell-Hornby, która nawoływała również do tego, aby uczelnie - zwłaszcza wschodnioeuropejskie - wyraźnie rozdzieliły studia thumaczeniowe od filologicznych (Snell-Hornby 1994, s. 433), a tym samym zmieniły podejście do nauczania thumaczenia. Choć od publikacji artykułu badaczki minęło już ponad 20 lat, wydaje się, że programy tłumaczeniowe w Polsce są zdominowane przez filologie i mało jest odrębnych studiów translatologicznych ${ }^{7}$. Inaczej jest $\mathrm{np} . \mathrm{w}$ Niemczech, gdzie kierunki translatologiczne mają długoletnią tradycję. Za przykład mogą posłużyć polonistyczne studia thumaczeniowe na Wydziale Lingwistyki Stosowanej i Kulturowej Uniwersytetu im. Jana Gutenberga w Moguncji (FTSK, JGU Mainz). Studia te, jak wiele innych programów tłumaczeniowych w Niemczech, mają w porównaniu z studiami filologicznymi ${ }^{8}$ jasno sprecyzowany charakter praktyczny i oferują studentom liczne zajęcia $\mathrm{z}$ thumaczenia $\mathrm{w}$ obu kierunkach (z polskiego na niemiecki i odwrotnie) zarówno w zakresie języka ogólnego, jak i tekstów literackich, ogólnospecjalistycznych, a także wstęp do tłumaczenia tekstów medialnych, np. napisów filmowych czy komiksów. Taka konstrukcja programu studiów thumaczeniowych o wysokim stopniu specjalizacji pokrywa się z ogólnym trendem do zwiększenia akademizacji zawodu thumacza (Caminade, Pym 1998, s. 283). Ponadto widać również dążenia do upraktycznienia programów kształcenia i zwiększenia stopnia specjalizacji (por. Gouadec 2007; Kiraly 2005; González-Davies, Scott-Tennent 2005; Kelly 2005; Pym 2008; Schäffner 2005; podaję za Biel 2011, s. 164).

Rozdzielenie filologii od translatoryki powinno znaleźć również odzwierciedlenie w kształceniu kompetencji przedtłumaczeniowej, czyli w głównej mierze we wzmacnianiu kompetencji lingwistycznej oraz modelowaniu typu pamięci. Niestety, z analizy programu studiów na Wydziale Tłumaczeniowym Uniwersytetu w Moguncji wynika, że tak nie jest. W obecnej siatce godzinowej nauczania uderzająca jest znikoma liczba godzin poświęconych na kształcenie językowe - są to zaledwie dwa moduły 90 minutowe, trwające w sumie 2 semestry. Wnioskować należy zatem, że również zajęcia tłumaczeniowe muszą stać się po części zajęciami z nauczania języka, podczas których umiejętności językowe będą zdobywane na zasadzie on the job, z wykorzystaniem dydaktyki top-down, wychodząc od poziomu tekstu i stopniowo zagłębiając się w poszczególne zagadnienia gramatyczne, składniowe bądź leksykalne. Takie rozwiązanie dydaktyczne niesie z pewnością obiecujące rezultaty, ale również szereg problemów związanych przede wszystkim z brakiem odpowiednich opracowań i metod dopasowanych do kształcenia językowego thumaczy.

\footnotetext{
${ }^{7}$ Obecnie są to kierunki w Warszawie, Poznaniu i Krakowie. Od 2020 roku również w Łodzi.

${ }^{8} \mathrm{Na}$ Uniwersytecie im. Jana Gutenberga w Moguncji można również studiować polonistykę na Wydziale Filozofii i Filologii.
} 
Pierwszy ze wymienionych problemów stanowi wspomniana przez Pyma konieczność nauczania języka obcego w sposób kontekstowy i zorientowany na przykłady. W opracowaniu specjalnego programu nauczania, uwzględniającego takie założenia, pomocne z pewnością byłyby najnowsze doniesienia z dziedziny glottodydaktyki, zwłaszcza prace zajmujące się podejściem zadaniowym (np. Janowska 2011) czy tzw. metodą content-based instruction (CBI), czyli nauczaniem poprzez dobór treści (np. Bednarska 2017). Trudność polega jednak na tym, że zróżnicowanie zadań czy wykorzystywane materiały będą silnie związane z dychotomią typu tłumaczenia. Podział na ścieżkę kształcenia tłumaczy pisemnych (zwykle na poziomie studiów licencjackich) i tłumaczy ustnych (na poziomie studiów magisterskich) oraz związany z tym asymetryczny nacisk na rozwój kompetencji uniemożliwia wykorzystywanie ogólnych programów do nauki języków obcych, które zakładają równomierne kształcenie poszczególnych sprawności zgodnie z Europejskim systemem opisu ksztatcenia językowego (2003). Wykorzystanie metody zadaniowej na zajęciach językowych jest jednak mocno ograniczone, gdyż dominującym typem zadań musi być thumaczenie. Jest to problematyczne, mimo że we współczesnych teoriach glottodydaktycznych elementy przekładu stają się jednym z narzędzi metodycznych, w innym stopniu niż miało to miejsce np. w metodzie gramatyczno-tłumaczeniowej ${ }^{9}$, to jednak nie w taki sposób, który odpowiadałby potrzebom kształcenia thumaczy. Chodzi tu o thumaczenie w duchu mediacji językowej, którego dydaktyka znacząco różni się od metod stosowanych na studiach thumaczeniowych ${ }^{10}$.

Kolejną trudnością jest również typowa dla studiów thumaczeniowych kombinacja językowa. W przeciwieństwie do filologii studenci translatoryki studiują dwa lub trzy języki obce w tzw. kombinacjach ABB bądź ACCC. Pierwszy wariant kształcenia przewiduje tłumaczenie z języka pierwszego (A) na dwa języki obce i odwrotnie, natomiast drugi wariant zakłada, że przyszły tłumacz będzie przekładał wyłącznie z trzech języków obcych na język pierwszy - wiąże się z tym oczywiście założenie, że w modelu ABB aktywne kompetencje lingwistyczne muszą być rozwijane intensywniej niż ma to miejsce w przypadku ACCC, w których większy nacisk położony jest na receptywną znajomość większej liczby języków.

$\mathrm{Na}$ koniec chciałbym zwrócić uwagę na jeszcze jeden aspekt kształcenia językowego thumaczy, który znacząco różni się od potrzeb kształcenia na filologii, a mianowicie na potrzebę doskonalenia języka pierwszego, względnie kontrastywnemu sposobowi nauczania w oparciu o język pierwszy. $Z$ przeprowadzonych rozmów ze studentami, którzy przyjechali zaraz po maturze w Polsce na studia przekładoznawcze na Wydziale Tłumaczeniowym JGU, wynika, że nierzadko

${ }^{9} \mathrm{O}$ ogólnym problemie wykorzystania metody gramatyczno-thumaczeniowej bądź elementów tłumaczenia w nauczaniu języka polskiego jako obcego pisałem w 2012 roku (Szafraniec 2012).

${ }^{10}$ Więcej o sposobach dydaktyzacji thumaczenia w celach nauczania języka obcego znaleźć można m.in. w E. Lipińska, A. Seretny (2016). O mediacji językowej i wykorzystaniu thumaczenia pisała m.in. I. Janowska (2017). 
czują się oni pewniej tłumacząc na język niemiecki aniżeli na polski. Ich zdaniem jest to skutek intensywnego treningu językowego w języku docelowym (w tym przypadku niemieckim) i niewystarczającej świadomości językowej w zakresie polszczyzny, zwłaszcza jeśli chodzi o zagadnienia związane z kulturą i etykietą językową, a także problemami stylistycznymi. Zjawisko traktowania kompetencji w języku ojczystym na studiach translatorycznych po macoszemu - na zasadzie domyślnej umiejętności lub ukształtowanej w toku edukacji przeduniwersyteckiej - zostało dostrzeżone również przez R. Sima, naukowca zajmującego się problematyką przekładu Biblii na języki afrykańskie. Jak słusznie zauważa badacz, dopiero aktywne i świadome nauczanie kompetencji języka ojczystego może w znacznym stopniu przyczynić się do sukcesu thumacza (Sim 2000, s. 173).

\section{BIBLIOGRAFIA}

Ballard M., 1984, La traduction relève-t-elle d'un pédagogie?, w: M. Ballard (red.) La traduction: de la théorie à la pratique, Lille.

Bednarska K., 2017, Stownictwo specjalistyczne w nauczaniu języka słoweńskiego jako obcego na kierunku lingwistyka dla biznesu [online], http://repozytorium.uni.lodz.pl:8080/xmlui/handle/11089/23546, [10.06.2020]

Biel Ł., 2011, Professional Realism in the Legal Translation Classroom, "Meta", t. 56(1), s. 162-178. https://doi.org/10.7202/1003515ar

Bloomfield L., 1933, Language, Chicago.

Caminade M., Pym A., 1998, Translator-training institutions, w: M. Baker (red.), Routledge Encyclopedia of Translation Studies, London, s. 280-285.

ESOKJ - Europejski system opisu ksztatcenia językowego: uczenie się, nauczanie, ocenianie, 2003, Warszawa.

Ervin S., Osgood Ch.E., 1954, Second Language Learning and Bilingualism, w: Ch.E. Osgood, T.A. Sebeok (red.), Psycholinguistics, Bloomington, s. 139-146.

González-Davies M., Scott-Tennent Ch., 2005, A problem-solving and student-centered approach to the translation of cultural references, "Meta", t. 50(1), s. 160-179. https://doi. org/10.7202/010666ar

Gouadec D., 2007, Translation as a Profession, Amsterdam.

Harris B., 1977, The Importance of Natural Translation, "Working Papers in Bilingualism", t. 12, s. $96-114$.

Harris B., Sherwood B., 1978, Translating as an Innate Skill, w: D. Gerver, H. Wallace Sinaiko (red.), Language, Interpretation and Communication, New York \& London, s. 155-170.

Janowska I., 2011, Podejście zadaniowe do nauczania i uczenia się języków obcych. Na przyktadzie języka polskiego, Kraków.

Janowska I., 2017, Mediacja i działania mediacyjne w dydaktyce języków obcych, „Języki Obce w Szkole", nr. 3, s. 80-86, http://jows.pl/sites/default/files/jows-3-2017_iwonajanowska.pdf [31.08.2020]

Kelly D., 2005, A Handbook for Translator Trainers. A Guide to Reflective Practice, Manchester.

Kiraly D., 2005, Project-Based Learning: a Case for Situated Translation, "Meta", t. 50(4), s. 1098-1111. https://doi.org/10.7202/012063ar

Koller W., 1979, Einführung in die Übersetzungswissenschaft, Heidelberg.

Krings H.P., 1986, Was in den Köpfen von Übersetzern vorgeht, Tübingen. 
Kussmaul P., 1995, Training the Translator, Amsterdam \& Philadelphia.

Lipińska E., Seretny A. (red.), 2016, Ttumaczenie dydaktyczne w nowoczesnym kształceniu językowym. Monografia zbiorowa, Kraków.

Lörscher W., 1991, Translation Performance, Translation Process, and Translation Strategies, Tubingen.

Orozco M., Hurtado Albir A., 2002, Measuring Translation Competence Acquisition, "Meta”, t. 47 (3), s. 375-402. https://doi.org/10.7202/008022ar

PACTE, 2000, Acquiring Translation Competence: Hypotheses and methodological problems in a research project, w: A. Beeby, D. Ensinger, M. Presas (red.), Investigating Translation, Amsterdam, s. 99-106. https://doi.org/10.1075/btl.32

PACTE 2003, Building a translation competence model, w: F. Alves (red.), Triangulating translation: perspectives in process oriented research, Amsterdam, s. 43-66. https://doi. org $/ 10.1075 / \mathrm{btl} .45$

Presas M., 1998, Los components de la competencia pretraductora en el marco del diseño curricular, w: I. García Izquierdo, J.M. Verdegal (red.), Los estudios de traducción: un reto didáctico, Castelló de la Plana, s. 131-134.

Presas M., 2000, Bilingual Competence and Translation Competence, w: Ch. Schäffner, B. Adab (red.), Developing Translation Competence, Amsterdam, s. 19-31. https://doi.org/10.1075/btl.38

Pym A., 2003, Redefining Translation Competence in an Electronic Age. In Defence of a Minimalist Approach, "Meta", t. 48(4), s. 481-497. https://doi.org/10.7202/008533ar

Pym A., 2008, Professional corpora: Teaching strategies for work with online documentation, translation memories, and content management, "Chinese Translators' Journal", t. 29(2), s. 41-45, https://usuaris.tinet.cat/apym/on-line/translation/2008_professional_corpora.pdf. [10.06.2020]

Pym A., 2013, Translation Skill-Sets in a Machine-Translation Age, "Meta" t. 58(3), s. 487-503. https://doi.org/10.7202/1025047ar

Schäffner Ch., 2005, Preparing students of translation for the real world: Needs, methods, constraints, w: J. Peeters, (red.), On the Relationships Between Translation Theory and Translation Practice, Frankfurt, s. 237-248.

Sim R., 2000, A Training Strategy for Translation Studies, w: Ch. Schäffner, B. Adab (red.), Developing Translation Competence, Amsterdam, s. 171-182. https://doi.org/10.1075/btl.38. $16 \operatorname{sim}$

Snell-Hornby M., 1994, New Translation Departments - Challenges of the Future, w: M. Snell-Hornby, F. Pöchhacker, K. Kaindl (red.), Translation Studies, An Interdiscipline, Amsterdam \& Philadelphia, s. 431-434.

Szafraniec K., 2012, Metoda gramatyczno-ttumaczeniowa oraz elementy przektadu w glottodydaktyce polonistycznej, „Acta Universitatis Lodziensis. Kształcenie Polonistyczne Cudzoziemców", t. 19, G. Zarzycka (red.), s. 93-103.

Weinreich U., 1968, Languages in Contact: Findings and Problems, Mouton.

Wills W., 1976, Perspectives and limitations of a didactic framework for the teaching of translation, w: R.W. Brislin, (red.), Translation, New York, s. 117-137.

Wilss W., 1982, The science of translation. Problems and Methods, Tübingen. 
Kamil Szafraniec

\section{TRANSLATION COMPETENCE TRAINING THEORETICAL AND METHODOLOGICAL CONSIDERATIONS}

Keywords: translation competence, methodology of foreign language acquisition, translation studies, didactics of translation, teaching Polish as a foreign language, translators' training programs.

Abstract. The aim of this article is to present selected definitions and concepts of translation competence, mainly based on works in English language. The author starts from the earliest works of generativists (Wills, Harris) and briefly describes the development of the work on the theoretical foundations of translation competence. In the following part of the article, the most important changes and trends in the research on competence will be presented - first of all, the achievements of the Spanish research group PACTE and the so-called Pym's minimalist definition. In the final part of the article the author will explore the question, what are the methodological implications arising from different definitions of translation competence. Based on M. Presas' theory of "pretranslation competence", he will point out the differences between the curricula of foreign language taught at modern language departments and the needs in the process of teaching language skills in translation studies. 